\title{
Fighting corruption and organised crime as a means of socio-economic development in south-east Europe
}

\section{Introduction}

Among the many difficulties that south-east European societies face, there are but two major obstacles which cause significant harm both to the socio-economic development of the region and to its path to unity within the continent. These are: corruption; and organised crime.

This article will explore, at a rather theoretical level, the correlation between corruptive behaviours and development. It will then examine current trends in corruption and organised crime in south-east Europe and explore and offer some strategies as to how to dismantle the political-criminal power structures throughout the region.

\section{Relationship between corruption and socio-economic development}

The road towards integration would indeed be longer pending fragile and unreformed institutional structures, a weak state of the rule of law and the flourishing of largely corrupt-based economies and organised crime. Letting such phenomena become 'an everyday affair' or a 'norm' will have far-reaching long-term consequences for the region. Corruption harms economic growth and development, as suggested by numerous empirical and other more theoretical studies (You and Khagram, 2004; Hellman, Jones and Kaufman, 2003; Leite and Weidmann, 2002; Shleifer and Vishny, 1993; Rose-Ackerman, 1975).

The damages caused to economic development are manifest in a variety of ways. More often, corruption distorts markets and fair competition, undermines the rule of law, damages government legitimacy, breeds dishonesty in society, erodes the private sector (Heineman, Jr. and Heimann, 2006) and even contributes to greater income inequality (You and Khagram, 2004; Gupta, Davoodi and Alonso-Terme, 2002; Li, Xu and Zou, 2000). Therefore, greater income inequality raises the chances of there being higher levels of corruption, and vice versa (You and Khagram, 2004). In fact, this reciprocal causation exists not only between inequality and corruption. It is considered to include all other variables, some of the most important of which include: economic development (per capita income) (Treisman, 2000; Paldam, 2002); trade openness characterised by economic competition and growth (Ades and Di Tella, 1999; Treisman, 2000); and a true process of democratisation, although it is held that democracy does not immediately bring an end to corruption - at least, not partial democratisation (Montinola and Jackman, 2002; Treisman, 2000). This causation scheme shows a somewhat complex dynamic created out of corruption and organised crime.

A more detailed analysis will follow, along with some problem-solving pathways on how to dismantle the political-criminal power structures which 'exist throughout the region' (USIP Special Report, 2002). 


\section{Current trends in corruption in south-eastern Europe}

The problem of corruption - defined here as the misuse of public or private office for personal gain - has been one of the most enduring dilemmas confronting governments throughout history and it remains one of the most serious problems in the region of south-east Europe nowadays, along with organised crime.

Table 1 presents the current state of corruption perceptions in western Balkans countries.

Table 1 - Corruption Perceptions Index figures for western Balkans countries

\begin{tabular}{|l|c|c|}
\hline Country & Position & Score \\
\hline Albania & 111 & 2.6 \\
\hline Bosnia and Herzegovina & 95 & 2.9 \\
\hline Croatia & 69 & 3.4 \\
\hline Macedonia & 108 & 2.7 \\
\hline Serbia & 91 & 3.0 \\
\hline
\end{tabular}

Source: 2006 Transparency International Corruption Perceptions Index, www.transparency.org

Amongst the western Balkans countries, Croatia has the lowest level of corruption perceptions and it also differs significantly from the level of corruption in other western Balkans countries. From the potential candidate countries (Albania, Bosnia \& Herzegovina and Serbia), Serbia stands at a somewhat better position although the difference between them is rather minimal.

Table 2 offers a better comparative overview of the state of corruption perceptions in the current three candidate countries: Croatia, Macedonia and Turkey.

Table 2 - Corruption Perceptions Index figures for EU candidate countries

\begin{tabular}{|l|c|c|}
\hline Country & Position & Score \\
\hline Croatia & 69 & 3.4 \\
\hline Macedonia & 108 & 2.7 \\
\hline Turkey & 60 & 3.8 \\
\hline
\end{tabular}

Source: 2006 Transparency International Corruption Perceptions Index, www.transparency.org

The figures in Table 2 show a better standing for Turkey compared to the other two current member candidates. Of the three, Macedonia seems to be the furthest be- 
hind. This suggests the need for further substantial efforts by Macedonia to advance its fight against corruption.

Table 3 shows the rank and score for the two most recent member states of the EU, Bulgaria and Romania. Given their recent membership of the EU and their regional background, it is worth comparing them with candidate and potential candidate countries.

Table 3 - Corruption Perceptions Index figures for most recent EU members

\begin{tabular}{|l|c|c|}
\hline Country & Position & Score \\
\hline Bulgaria & 57 & 4.0 \\
\hline Romania & 88 & 3.1 \\
\hline
\end{tabular}

Source: 2006 Transparency International Corruption Perceptions Index, www.transparency.org

As these figures show, there is an obvious difference between corruption perceptions concerning Bulgaria and Romania themselves. It is not significant, but Bulgaria's score is lowest compared to both candidate and potential candidate countries. This is, however, not the case with Romania, which is behind both Turkey and Croatia. What this would suggest is that, at least in one case, candidate countries may be ahead of actual member states. Or, this may be interpreted as a fulfilment of the required criteria for membership by candidate countries in the relevant sector.

Table 4 presents these data from a comparative perspective, while Table 5 shows the ranking at the level of south-east Europe.

Table 4 - Corruption Perceptions Index figures for most recent EU members, candidate countries and potential candidates

\begin{tabular}{|c|c|c|c|c|c|c|c|c|}
\hline & \multicolumn{2}{|c|}{$\begin{array}{l}\text { Recent mem- } \\
\text { ber states }\end{array}$} & \multicolumn{3}{|c|}{ Candidates } & \multicolumn{3}{|c|}{ Potential candidates } \\
\hline & $\begin{array}{l}\text { Bul- } \\
\text { garia }\end{array}$ & $\begin{array}{l}\text { Roma- } \\
\text { nia }\end{array}$ & Croatia & $\begin{array}{l}\text { Mace- } \\
\text { donia }\end{array}$ & Turkey & $\begin{array}{l}\mathrm{Al}- \\
\text { ba- } \\
\text { nia }\end{array}$ & $\begin{array}{c}\text { Bosnia } \\
\text { and } \\
\text { Herze- } \\
\text { govina }\end{array}$ & Serbia \\
\hline Position & 57 & 88 & 69 & 108 & 60 & 111 & 94 & 91 \\
\hline Score & 4.0 & 3.1 & 3.4 & 2.7 & 3.8 & 2.6 & 2.9 & 3.0 \\
\hline
\end{tabular}

Source: 2006 Transparency International Corruption Perceptions Index, www.transparency.org 
Table 5 - Ranking of south-east Europe countries

\begin{tabular}{|l|l|c|}
\hline Rank & \multicolumn{1}{|c|}{ Country } & Score \\
\hline 1 & Bulgaria & 4.0 \\
\hline 2 & Turkey & 3.8 \\
\hline 3 & Croatia & 3.4 \\
\hline 4 & Romania & 3.1 \\
\hline 5 & Serbia & 3.0 \\
\hline 6 & Bosnia and Herzegovina & 2.9 \\
\hline 7 & Macedonia & 2.7 \\
\hline 8 & Albania & 2.6 \\
\hline
\end{tabular}

Regarding an overview of corruption perceptions at the global level, Table 6 is instructive.

Table 6 - International Corruption Perceptions Index (CPI): country rank (CPI score)

\begin{tabular}{|c|c|c|c|c|c|}
\hline Finland & $\begin{array}{l}1 \\
\text { [9.6] }\end{array}$ & Namibia & $\begin{array}{l}56 \\
{[4.1]}\end{array}$ & Albania & $\begin{array}{l}111 \\
{[2.6]}\end{array}$ \\
\hline Iceland & $\begin{array}{l}2 \\
{[9.6]}\end{array}$ & Bulgaria & $\begin{array}{l}57 \\
{[4.0]}\end{array}$ & Guatemala & $\begin{array}{l}112 \\
{[2.6]}\end{array}$ \\
\hline New Zealand & $\begin{array}{l}3 \\
{[9.6]}\end{array}$ & El Salvador & $\begin{array}{l}58 \\
{[4.0]}\end{array}$ & Kazakhstan & $\begin{array}{l}113 \\
{[2.6]}\end{array}$ \\
\hline Denmark & $\begin{array}{l}4 \\
{[9.5]}\end{array}$ & Colombia & $\begin{array}{l}59 \\
{[3.9]}\end{array}$ & Laos & $\begin{array}{l}114 \\
{[2.6]}\end{array}$ \\
\hline Singapore & $\begin{array}{l}5 \\
{[9.4]}\end{array}$ & Turkey & $\begin{array}{l}60 \\
{[3.8]}\end{array}$ & Nicaragua & $\begin{array}{l}115 \\
{[2.6]}\end{array}$ \\
\hline Sweden & $\begin{array}{l}6 \\
{[9.2]}\end{array}$ & Jamaica & $\begin{array}{l}61 \\
{[3.7]}\end{array}$ & Paraguay & $\begin{array}{l}116 \\
{[2.6]}\end{array}$ \\
\hline Switzerland & $\begin{array}{l}7 \\
{[9.1]}\end{array}$ & Poland & $\begin{array}{l}62 \\
{[3.7]}\end{array}$ & East Timor & $\begin{array}{l}117 \\
{[2.6]}\end{array}$ \\
\hline Norway & $\begin{array}{l}8 \\
{[8.8]}\end{array}$ & Lebanon & $\begin{array}{l}63 \\
{[3.6]}\end{array}$ & Vietnam & $\begin{array}{l}118 \\
{[2.6]}\end{array}$ \\
\hline Australia & $\begin{array}{l}9 \\
{[8.7]}\end{array}$ & Seychelles & $\begin{array}{l}64 \\
{[3.6]}\end{array}$ & Yemen & $\begin{array}{l}119 \\
{[2.6]}\end{array}$ \\
\hline
\end{tabular}




\begin{tabular}{|c|c|c|c|c|c|}
\hline Netherlands & $\begin{array}{l}10 \\
{[8.7]}\end{array}$ & Thailand & $\begin{array}{l}65 \\
{[3.6]}\end{array}$ & Zambia & $\begin{array}{l}120 \\
{[2.6]}\end{array}$ \\
\hline Austria & $\begin{array}{l}11 \\
{[8.6]}\end{array}$ & Belize & $\begin{array}{l}66 \\
{[3.5]}\end{array}$ & Benin & $\begin{array}{l}121 \\
{[2.5]}\end{array}$ \\
\hline Luxembourg & $\begin{array}{l}12 \\
{[8.6]}\end{array}$ & Cuba & $\begin{array}{l}67 \\
{[3.5]}\end{array}$ & Gambia & $\begin{array}{l}122 \\
{[2.5]}\end{array}$ \\
\hline United Kingdom & $\begin{array}{l}13 \\
{[8.6]}\end{array}$ & Grenada & $\begin{array}{l}68 \\
{[3.5]}\end{array}$ & Guyana & $\begin{array}{l}123 \\
{[2.5]}\end{array}$ \\
\hline Canada & $\begin{array}{l}14 \\
{[8.5]}\end{array}$ & Croatia & $\begin{array}{l}69 \\
{[3.4]}\end{array}$ & Honduras & $\begin{array}{l}124 \\
{[2.5]}\end{array}$ \\
\hline Hong Kong & $\begin{array}{l}15 \\
{[8.3]}\end{array}$ & Brazil & $\begin{array}{l}70 \\
{[3.3]}\end{array}$ & Nepal & $\begin{array}{l}125 \\
{[2.5]}\end{array}$ \\
\hline Germany & $\begin{array}{l}16 \\
{[8.0]}\end{array}$ & China & $\begin{array}{l}71 \\
{[3.3]}\end{array}$ & Philippines & $\begin{array}{l}126 \\
{[2.5]}\end{array}$ \\
\hline Japan & $\begin{array}{l}17 \\
{[7.6]}\end{array}$ & Egypt & $\begin{array}{l}72 \\
{[3.3]}\end{array}$ & Russia & $\begin{array}{l}127 \\
{[2.5]}\end{array}$ \\
\hline France & $\begin{array}{l}18 \\
{[7.4]}\end{array}$ & Ghana & $\begin{array}{l}73 \\
{[3.3]}\end{array}$ & Rwanda & $\begin{array}{l}128 \\
{[2.5]}\end{array}$ \\
\hline Ireland & $\begin{array}{l}19 \\
{[7.4]}\end{array}$ & India & $\begin{array}{l}74 \\
{[3.3]}\end{array}$ & Swaziland & $\begin{array}{l}129 \\
{[2.5]}\end{array}$ \\
\hline Belgium & $\begin{array}{l}20 \\
{[7.3]}\end{array}$ & Mexico & $\begin{array}{l}75 \\
{[3.3]}\end{array}$ & Azerbaijan & $\begin{array}{l}130 \\
{[2.4]}\end{array}$ \\
\hline Chile & $\begin{array}{l}21 \\
{[7.3]}\end{array}$ & Peru & $\begin{array}{l}76 \\
{[3.3]}\end{array}$ & Burundi & $\begin{array}{l}131 \\
{[2.4]}\end{array}$ \\
\hline USA & $\begin{array}{l}22 \\
{[7.3]}\end{array}$ & Saudi Arabia & $\begin{array}{l}77 \\
{[3.3]}\end{array}$ & $\begin{array}{l}\text { Central African } \\
\text { Republic }\end{array}$ & $\begin{array}{l}132 \\
{[2.4]}\end{array}$ \\
\hline Spain & $\begin{array}{l}23 \\
{[6.8]}\end{array}$ & Senegal & $\begin{array}{l}78 \\
{[3.3]}\end{array}$ & Ethiopia & $\begin{array}{l}133 \\
{[2.4]}\end{array}$ \\
\hline Barbados & $\begin{array}{l}24 \\
{[6.7]}\end{array}$ & Burkina Faso & $\begin{array}{l}79 \\
{[3.2]}\end{array}$ & Indonesia & $\begin{array}{l}134 \\
{[2.4]}\end{array}$ \\
\hline Estonia & $\begin{array}{l}25 \\
{[6.7]}\end{array}$ & Lesotho & $\begin{array}{l}80 \\
{[3.2]}\end{array}$ & $\begin{array}{l}\text { Papua New Guin- } \\
\text { ea }\end{array}$ & $\begin{array}{l}135 \\
{[2.4]}\end{array}$ \\
\hline Macao & $\begin{array}{l}26 \\
{[6.6]}\end{array}$ & Moldova & $\begin{array}{l}81 \\
{[3.2]}\end{array}$ & Togo & $\begin{array}{l}136 \\
{[2.4]}\end{array}$ \\
\hline Portugal & $\begin{array}{l}27 \\
{[6.6]}\end{array}$ & Morocco & $\begin{array}{l}82 \\
{[3.2]}\end{array}$ & Zimbabwe & $\begin{array}{l}137 \\
{[2.4]}\end{array}$ \\
\hline Malta & $\begin{array}{l}28 \\
{[6.4]}\end{array}$ & $\begin{array}{l}\text { Trinidad and To- } \\
\text { bago }\end{array}$ & $\begin{array}{l}83 \\
{[3.2]}\end{array}$ & Cameroon & $\begin{array}{l}138 \\
{[2.3]}\end{array}$ \\
\hline Slovenia & $\begin{array}{l}29 \\
{[6.4]}\end{array}$ & Algeria & $\begin{array}{l}84 \\
{[3.1]}\end{array}$ & Ecuador & $\begin{array}{l}139 \\
{[2.3]}\end{array}$ \\
\hline
\end{tabular}


Bruno S. Sergi and Qerim Qerimi

\begin{tabular}{|c|c|c|c|c|c|}
\hline Uruguay & $\begin{array}{l}30 \\
{[6.4]}\end{array}$ & Madagascar & $\begin{array}{l}85 \\
{[3.1]}\end{array}$ & Niger & $\begin{array}{l}140 \\
{[2.3]}\end{array}$ \\
\hline $\begin{array}{l}\text { United Arab Emir- } \\
\text { ates }\end{array}$ & $\begin{array}{l}31 \\
{[6.2]}\end{array}$ & Mauritania & $\begin{array}{l}86 \\
{[3.1]}\end{array}$ & Venezuela & $\begin{array}{l}141 \\
{[2.3]}\end{array}$ \\
\hline Bhutan & $\begin{array}{l}32 \\
{[6.0]}\end{array}$ & Panama & $\begin{array}{l}87 \\
{[3.1]}\end{array}$ & Angola & $\begin{array}{l}142 \\
{[2.2]}\end{array}$ \\
\hline Qatar & $\begin{array}{l}33 \\
{[6.0]}\end{array}$ & Romania & $\begin{array}{l}88 \\
{[3.1]}\end{array}$ & Republic of Congo & $\begin{array}{l}143 \\
{[2.2]}\end{array}$ \\
\hline Israel & $\begin{array}{l}34 \\
{[5.9]}\end{array}$ & Sri Lanka & $\begin{array}{l}89 \\
{[3.1]}\end{array}$ & Kenya & $\begin{array}{l}144 \\
{[2.2]}\end{array}$ \\
\hline Taiwan & $\begin{array}{l}35 \\
{[5.9]}\end{array}$ & Gabon & $\begin{array}{l}90 \\
{[3.0]}\end{array}$ & Kyrgyzstan & $\begin{array}{l}145 \\
{[2.2]}\end{array}$ \\
\hline Bahrain & $\begin{array}{l}36 \\
{[5.7]}\end{array}$ & Serbia & $\begin{array}{l}91 \\
{[3.0]}\end{array}$ & Nigeria & $\begin{array}{l}146 \\
{[2.2]}\end{array}$ \\
\hline Botswana & $\begin{array}{l}37 \\
{[5.6]}\end{array}$ & Surinam & $\begin{array}{l}92 \\
{[3.0]}\end{array}$ & Pakistan & $\begin{array}{l}147 \\
{[2.2]}\end{array}$ \\
\hline Cyprus & $\begin{array}{l}38 \\
{[5.6]}\end{array}$ & Argentina & $\begin{array}{l}93 \\
{[2.9]}\end{array}$ & Sierra Leone & $\begin{array}{l}148 \\
{[2.2]}\end{array}$ \\
\hline Oman & $\begin{array}{l}39 \\
{[5.4]}\end{array}$ & Armenia & $\begin{array}{l}94 \\
{[2.9]}\end{array}$ & Tajikistan & $\begin{array}{l}149 \\
{[2.2]}\end{array}$ \\
\hline Jordan & $\begin{array}{l}40 \\
{[5.3]}\end{array}$ & $\begin{array}{l}\text { Bosnia and Herze- } \\
\text { govina }\end{array}$ & $\begin{array}{l}95 \\
{[2.9]}\end{array}$ & Turkmenistan & $\begin{array}{l}150 \\
{[2.2]}\end{array}$ \\
\hline Hungary & $\begin{array}{l}41 \\
{[5.2]}\end{array}$ & Eritrea & $\begin{array}{l}96 \\
{[2.9]}\end{array}$ & Belarus & $\begin{array}{l}151 \\
{[2.1]}\end{array}$ \\
\hline Mauritius & $\begin{array}{l}42 \\
{[5.1]}\end{array}$ & Syria & $\begin{array}{l}97 \\
{[2.9]}\end{array}$ & Cambodia & $\begin{array}{l}152 \\
{[2.1]}\end{array}$ \\
\hline South Korea & $\begin{array}{l}43 \\
{[5.1]}\end{array}$ & Tanzania & $\begin{array}{l}98 \\
{[2.9]}\end{array}$ & Ivory Coast & $\begin{array}{l}153 \\
{[2.1]}\end{array}$ \\
\hline Malaysia & $\begin{array}{l}44 \\
{[5.0]}\end{array}$ & $\begin{array}{l}\text { Dominican Repub- } \\
\text { lic }\end{array}$ & $\begin{array}{l}99 \\
{[2.8]}\end{array}$ & Equatorial Guinea & $\begin{array}{l}154 \\
{[2.1]}\end{array}$ \\
\hline Italy & $\begin{array}{l}45 \\
{[4.9]}\end{array}$ & Georgia & $\begin{array}{l}100 \\
{[2.8]}\end{array}$ & Uzbekistan & $\begin{array}{l}155 \\
{[2.1]}\end{array}$ \\
\hline Czech Republic & $\begin{array}{l}46 \\
{[4.8]}\end{array}$ & Mali & $\begin{array}{l}101 \\
{[2.8]}\end{array}$ & Bangladesh & $\begin{array}{l}156 \\
{[2.0]}\end{array}$ \\
\hline Kuwait & $\begin{array}{l}47 \\
{[4.8]}\end{array}$ & Mongolia & $\begin{array}{l}102 \\
{[2.8]}\end{array}$ & Chad & $\begin{array}{l}157 \\
{[2.0]}\end{array}$ \\
\hline Lithuania & $\begin{array}{l}48 \\
{[4.8]}\end{array}$ & Mozambique & $\begin{array}{l}103 \\
{[2.8]}\end{array}$ & $\begin{array}{l}\text { Democratic Re- } \\
\text { public of Congo }\end{array}$ & $\begin{array}{l}158 \\
{[2.0]}\end{array}$ \\
\hline Latvia & $\begin{array}{l}49 \\
{[4.7]}\end{array}$ & Ukraine & $\begin{array}{l}104 \\
{[2.8]}\end{array}$ & Sudan & $\begin{array}{l}159 \\
{[2.0]}\end{array}$ \\
\hline
\end{tabular}




\begin{tabular}{|c|c|c|c|c|c|}
\hline Slovakia & $\begin{array}{l}50 \\
{[4.7]}\end{array}$ & Bolivia & $\begin{array}{l}105 \\
{[2.7]}\end{array}$ & Guinea & $\begin{array}{l}160 \\
{[1.9]}\end{array}$ \\
\hline South Africa & $\begin{array}{l}51 \\
{[4.6]}\end{array}$ & Iran & $\begin{array}{l}106 \\
{[2.7]}\end{array}$ & Iraq & $\begin{array}{l}161 \\
{[1.9]}\end{array}$ \\
\hline Tunisia & $\begin{array}{l}52 \\
{[4.6]}\end{array}$ & Libya & $\begin{array}{l}107 \\
{[2.7]}\end{array}$ & Myanmar & $\begin{array}{l}162 \\
{[1.9]}\end{array}$ \\
\hline Dominica & $\begin{array}{l}53 \\
{[4.5]}\end{array}$ & Macedonia & $\begin{array}{l}108 \\
{[2.7]}\end{array}$ & Haiti & $\begin{array}{l}163 \\
{[1.8]}\end{array}$ \\
\hline Greece & $\begin{array}{l}54 \\
{[4.4]}\end{array}$ & Malawi & $\begin{array}{l}109 \\
{[2.7]}\end{array}$ & & \\
\hline Costa Rica & $\begin{array}{l}55 \\
{[4.1]}\end{array}$ & Uganda & $\begin{array}{l}110 \\
{[2.7]}\end{array}$ & & \\
\hline
\end{tabular}

Source: 2006 Transparency International Corruption Perceptions Index, www.transparency.org

As can be noted from the data presented in Table 6, differences may exist in the nature and scope of corrupt behaviour and the extent to which anti-corruption measures are enforced, but the phenomenon can be found at all times and within virtually every political system. It can also be found within the private sector. Indeed, the linkage between public and private sector corruption is an area of particular concern in south-east Europe.

Recently, the effort to combat corruption has moved to the centre of the debate about good governance and economic growth. The impetus behind this move has come from many sources. On the donor side, the end of the Cold War has reduced the willingness of countries providing aid to overlook financial improprieties in the light of broader geo-political interests. Donor fatigue has also placed increasing pressure upon foreign assistance agencies to demonstrate that they are delivering maximum value for money. Thirdly, many multinational corporations have come to believe their interests are better served by open and transparent competition (Klitgaard, 1988).

It has been noted in various publications that economic activity in south-east Europe is often associated with, among others, smuggling, extortion and tax evasion (Meyer and Nash, 2002). Such factors have a considerable impact on the ability of the region's governments to develop and stabilise their economies. This is certainly an obstacle in attracting foreign investment. In this respect, establishing the rule of law is critical: it is the number one priority in tackling these issues, while it would also act as a preventive mechanism regarding any possible violent action. The Stabilisation and Association Process provides a helpful guideline on the adoption of relevant policies and strategies to strengthen the rule of law.

The major thrust of the efforts of south-east European governments will have to address this problem both as a matter of policy and as a part of broader programmes on governance and capacity building. There are two priority areas in which governments in the region will have to concentrate their broader governance effort: policy dialogue directed toward economic liberalisation; and public administration reform. The liberalisation of licensing regimes, the opening up of access to foreign exchange 
markets, the reduction of administered prices, the removal of subsidies and soft loans to favoured companies and the introduction of a clear distinction between production and regulatory functions are all ways in which policy changes can level the playing field and reduce opportunities for corrupt or illicit behaviour.

The international community, through its missions in the region, may also be called upon to assist in pursuing explicit anti-corruption programmes. Such assistance could include efforts to develop national anti-corruption strategies; to improve the ability of the courts to try corruption cases; to respond to requests from legislators and government officials for legal or technical assistance in drafting anti-corruption statutes or professional codes of conduct; and to strengthen the legal mechanisms for the review of administrative activities, for example to improve the capacity of anti-corruption agencies to detect or prosecute illicit behaviour.

The international community will need to consider supporting regional anti-corruption efforts, among others through: conferences, seminars, workshops and training activities; research and publications dealing with anti-corruption issues; and possible collaboration with local and international NGOs whose mission or work programme advances such initiatives. With respect to anti-corruption measures, we recommend the following measures in programming and project management which could entail the notion of an 'EU factor':

- continue to expand the international community's assistance, especially efforts from the European Union concerning governance and capacity building with particular attention to promoting market liberalisation and public administration reform

- strengthen key institutions for advancing transparency and accountability in both central and local government institutions

- upgrade the quality of supervision during project implementation and strengthen project review missions

- inspire anti-corruption policies.

Ultimately, the benefits of undertaking these actions are of mutual interest for both south-east European countries and the EU, since these activities have serious implications both for established democracies and democratising countries in the region (Qerimi, 2005).

\section{Organised crime}

Organised crime, as corruption, poses another immediate challenge to the south-east European political scene, undermining the social and economic order. Another negative consequence is that it creates a major barrier to political, economic and social development in south-east Europe, while challenging the fragile democracies of the region and giving further rise to the level of inequality in south-east European societies.

A clear definition would at least provide a formal tool in addressing organised crime through legal settings. Such clarity would also help identify the basic features of the phenomenon. A widely-shared definition can be found in the United Nations Convention against Transnational Organised Crime, which reserves the term 'organised criminal group' for:

A structured group of three or more persons, existing for a period of time and acting in concert with the aim of committing one or more serious crimes or offences established in accord- 
ance with this Convention, in order to obtain, directly or indirectly, a financial or other material benefit ${ }^{1}$ (Art. 2 (a)).

The primary aim of organised crime is thus profit, characterised by the use of criminal activities carried out by people or groups of people operating in a well- or highly-organised manner.

Both corruption and organised crime are strongly present throughout the region, including in those countries that joined the EU in January 2007. A few months before its accession to the EU, Bulgaria was urged by EU Enlargement Commissioner Olli Rehn to show:

Concrete, tangible results in fighting high-level corruption and organised crime. (Southeast European Times, 2006).

A new study conducted by researchers at the Transnational Crime and Corruption Center at American University in Washington DC has suggested that it may take thirty years or more to eradicate organised crime networks and to establish the rule of law in the south-east Europe region. The principal reasons lie with the current weak state of the rule of law and the lack of an independent judiciary (Corpora and Shelley, 2002). South-east European societies are still struggling to establish well-functioning multi-ethnic models of existence although, in the field of organised crime, multi-ethnic collaboration is already strongly present (USIP Special Report, 2002). Organised crime structures in south-east Europe operate via informal networks that are often linked to security/intelligence agencies or extremist political forces (Corpora and Shelley, 2002; USIP Special Report, 2002).

Considering the root causes of organised crime in south-east Europe would enable us better to grasp the different range of issues involved and to come to better solutions on how to tackle these challenges. The most critical area in need of intervention remains the strengthening of the rule of law, consisting of sound judicial systems and efficient enforcement and border management institutions that are truly functional. Law enforcement and judicial personnel are often encouraged to participate or make concessions to corrupt and organised crime activities due to low salaries. This element should be considered in addressing corruption and organised crime.

Co-operation among regional governments and with the EU and other international agencies provides another means to be added to the system of counter measures. The international presence in the region can significantly improve the ability and capacities of local authorities to fight organised crime. Organisations such as OSCE and Interpol can further facilitate the process by providing direct assistance in both capacity building and in the investigation and prosecution of criminal activities. Close co-operation between regional leaders and their continuing commitment towards fighting organised crime and corruption should be maintained. In particular, southeast European governments should remain committed to implementing the measures set forth in the București Declaration of the Ministers of Justice and Home Affairs (JHA) from the States Participating in the South-East European Co-operation Process

1 See United Nations Convention against Transnational Organised Crime, G.A. Res. 25, annex I, UN GAOR, 55th Sess., Supp. No. 49, at 44, UN Doc. A/45/49 (Vol. I) (2001). 
(SEECP) on a Joint Campaign to Fight Organised Crime and Corruption in SouthEast Europe. ${ }^{2}$ Ratifying, monitoring and bringing the national legislations in line with the provisions of the United Nations Convention against Transnational Organised Crime and the United Nations Convention against Corruption would provide additional means of action.

Trade openness through increased economic competition and economic growth would further add a significant impact in reducing levels of corruption.

This multi-level and multi-measure approach seems to provide the most efficient tool for fighting corruption and organised crime. More precisely, a 'four Is' approach (i.e. information, interaction, incentives and institutions) could play a significant role here. Shortly elaborated, the 'four Is' system stands, contributes and operates in a rather integrated and comprehensive manner:

1. information serves the purpose of expressing the positions of the parties involved, offering clear guidelines on the process and outlining the pathways. This element is fundamental to having informed and sustained decisions. It also encompasses the maintenance of regular channels of communication and the exchange of information in the context of both institutional and non-institutional settings

2. interaction includes a process of genuine co-operation between the parties, as well as a close relationship and the ability to overcome obstacles and reach compromises that are in the common global interest

3. incentives help transform the transition and create sustainability, provided they are used in a way that best contributes to the establishment of accountable and responsible institutions and to the maximisation of the access of everyone to all the goal values. It is important to get the incentives right and on time

4. institutions are broadly-defined as norms, expectations, rules and organisations, or otherwise structures of expectations, concerning who, with what qualifications and mode of selection, is authorised to make which decisions by what criteria and within what procedures. The ultimate concern of the institutions is, and should remain, the individual human being who may act either alone or in association with different associations or groups.

The four elements work as a system of complementary settings, so giving due weight to this system and implementing it in practical modes of policy interactions would have a considerable impact, as well as enhancing the fight against corruption and organised crime. In other words - and further simplifying this approach - the maintenance of (a) proper channels of communication, (b) regular interaction processes between varying levels and different agencies, including the general public, and (c) receiving and making proper use of the incentives that should be used in and for (d) establishing the proper institutional arrangements and initiatives capable of pro-

2 For further detail on the specific measures outlined in the București Declaration, see the Joint Statement of the Ministers of Justice and Home Affairs from the States Participating in the South-East European Co-operation Process (SEECP) on a Joint Campaign to Fight Organised Crime and Corruption in South-Eastern Europe, București, 18 May 2004, available at: http://www.mae.ro/seecp/main7.html. 
ducing, promoting and executing successful policies in the field of anti-organised crime or anti-corruption would be of paramount importance.

\section{Re-thinking the reform}

The separation of powers between national and local authorities and the maintenance of checks and balances would create an unprecedented incentive to uncover and prosecute corruption. The role that the separation of powers can play has been suggested by various studies (Fishback, Kantor and Wallis, 2005; Bodenhorn, 2004).

An independent judiciary would add much to a successful legal prosecution. In fact, a corrupt judiciary means there would be hardly any merited legal penalties for corrupt officials. There are still chances that judges who are themselves corrupt may convict corrupt politicians if they do not share the same political interests or do not belong to the same political party; however, they would still be reluctant to apply the same penalties for corrupt politicians from their own political line. Raising professionalism among members of the judiciary, along with income, would help move significantly the success of fighting corruption in south-east Europe. A well-trained professional judge lowers the chances of him or her being at the same time a loyal collaborator or a corrupt politician. In addition, an increase in income for judges would further challenge corrupt officials. Special security measures may be considered for members of the judiciary in cases deemed threatening for the physical integrity of judges or which may disrupt, or in any way affect the outcome of, justice.

A legislative body which passes the necessary legislation for the successful battle against corruption and organised crime is another important tool. International organisations have, as already indicated, a role to play in drafting relevant legislation. Pertinent international instruments, such as the UN Convention against Transnational Organised Crime and the UN Convention against Corruption should be ratified and strictly observed by all south-east Europe member states.

The rise of the independent media is another critical factor to reform political corruption in south-east Europe. Many new agencies are affiliated to, or in some way supported by, corrupt political groups so facts are often hidden. Dropping party affiliations would be decisive in exposing the factual situation. In doing so, well-trained professional reporters and a media which can stand financially independent of political organisations are a conditio sine qua non. The presence of investigative reporters of the type of Robert Woodward and Carl Bernstein of the Washington Post would have provided a major contribution to uncovering the malfeasance of public officials. Empirical research has shown that the media has played a major role in exposing corruption scandals in countries which have been successful in fighting corruption, such as the United States that is, nowadays, ranked among the lowest 10 per cent of countries worldwide (Glaeser and Goldin, 2004). A research paper by Gentzkow, Glaeser and Goldin (2004), examining the decline of corruption in America's polity, economy and society, links the significant decrease of corruption in the period between 1870 and 1920 with the rise of an informative and less partisan press, as well as an expansion of the press in circulation, which:

Was one of the reasons why the corruption of the Gilded Age was sharply reduced during the subsequent Progressive Era. 
Providing information to the public on the corrupt behaviour of certain politicians would be likely to make them refrain from such corrupt practices; the costs of the revealed corruption could be too high for their political career. In addition, a greater level of competition, both in political and business affairs, makes corrupt activities and charges more likely to be reported (Glaeser and Goldin, 2004).

It can be seen in this discussion that it is tough since there is neither a single cause factor nor a single solution to such complex issues. Instead, we propose a shifting of the focus to a multi-measure approach while keeping the focus along the lines suggested herein. Above all, what Joseph Stiglitz refers to as the 'openness in process,' which would:

Contribute to a more open, democratic society,

could play a role (Stiglitz, 1998). The significance of such openness is particularly striking when one considers that most corrupt economies are considered closed economies $^{3}$ (Svensson, 2005). The spread of education, an independent and professional media and the creation of a middle class would be more than a wise investment: in fact, these are necessary tools in achieving the strategic goal of a free, open and democratic society. However, it is equally important that the process genuinely promotes, in parallel, democratisation, political equality and economic equality. The lack of any one of these would have an impact on the others. A more focused, comprehensive or integrated and systematic action is needed, after all. Such an action, and not rhetoric, should aim at shaping institutions and social behaviour in such a way that the best administrative, economic and institutional practices are used where some ethical values are instilled, goal values widely shaped and shared, and the best quality of life is promoted. A corrupt society or region is simply not a choice; it is the enemy of an open, prosperous and value-oriented south-east Europe and runs contrary to the most indispensable aim of making the region self-sustainable and part of a free and larger Europe.

\section{References}

Ades, Alberto and Rafael Di Tella (1999) 'Rents, Competition and Corruption' American Economic Review 89(4): 982-994.

Bodenhorn, Howard (2004) Bank Chartering and Political Corruption in Antebellum New York: Free Banking as Reform NBER Working Papers 10479, National Bureau of Economic Research.

Corpora, Christopher and Louise Shelley (2002) Tragedy, Transition and Transformation: The Local-International Nexus of Transnational Organised Crime in the Former Yugoslav Republics A Publication of the East European Studies Program at the Woodrow Wilson International Center for Scholars.

3 Openness is measured through the criteria developed by Sachs and Warner (1995). They consider an economy to be 'closed' if one of these five criteria are met: 1) average tariff rates above 40 per cent; 2) non-tariff barriers that cover more than 40 per cent of all imports; 3 ) a socialist economic system; 4) a state monopoly on major exports; and 5) the black market premium exceeded 20 per cent during the 1970s or 1980s. 
Gentzkow, Matthew, Edward L. Glaeser and Claudia Goldin (2004) The Rise of the Fourth Estate: How Newspapers became Informative and Why It Mattered NBER Working Papers 10791, National Bureau of Economic Research.

Glaeser, Edward L and Claudia Goldin (2004) Corruption and Reform: An Introduction NBER Working Paper No. W10775, National Bureau of Economic Research.

Gupta, Sanjeev, Hamid R. Davoodi and Rosa Alonso-Terme (2002) 'Does Corruption Affect Income Inequality and Poverty?’ Economics of Governance 3: 23-45.

Heineman, Ben W, Jr. and Fritz Heimann (2006) 'The Long War Against Corruption' Foreign Affairs May/June: 75-86.

Hellman, Joel, Geraint Jones and Daniel Kaufmann (2003) 'Seize the State, Seize the Day: State Capture, Corruption and Influence in Transition' Journal of Comparative Economics 31(4): 751-773.

Klitgaard, Robert (1988) Controlling corruption Berkeley: University of California Press.

Leite, Carlos and Jens Weidmann (2002) 'Does Mother Nature Corrupt? Natural Resources, Corruption and Economic Growth' in George T. Abed and Sanjeev Gupta (eds.) Governance, Corruption and Economic Performance Washington, DC: International Monetary Fund.

Li, Hongyi, Lixin Colin Xu and Heng-fu Zou (2000) 'Corruption, Income Distribution and Growth' Economic and Politics 20(2): 155-182.

Montinola, Gabriella and Robert Jackman (2002) 'Sources of Corruption: A CrossCountry Study’ British Journal of Political Science 32(1): 147-170.

Paldam, Martin (2002) The Cross-Country Pattern of Corruption: Economics, Culture and the Seesaw Dynamics European Journal of Political Economy 18(2): 215240.

Qerimi, Qerim (2003) 'South-East Europe's EU Integration: Dreams and Realities South-East Europe Review for Labour and Social Affairs 5(4): 43-56.

Qerimi, Qerim (2005) 'Human Values-Based Approach to Development. Amartya Sen and Central Eastern Europe' in Bruno S. Sergi and William T. Bagatelas (eds.) Ethical Implications of Post-communist Transition Economics and Politics in Europe Bratislava: Iura Edition.

Qerimi, Qerim R. and Bruno S. Sergi (2006) 'On the Relevance of the EU as a Means of Spurring a Socially-Sustainable South-East Europe' South-East Europe Review for Labour and Social Affairs 8(3): 111-120.

Rose-Ackerman, Susan (1978) Corruption: A Study in Political Economy New York: Academic Press.

Sachs, Jeffrey D. and Andrew M. Warner (1995) Economic reform and the process of global integration Brookings Papers on Economic Activity: 1-118.

Sergi, Bruno S (1997) 'How to Speed Up Growth and Keep Debts at Bay?' Transition Newsletter (World Bank) 8(6): 15-16. 
Sergi, Bruno S (2003a) 'FDI and the Balkans: A Regional Investment Agency and Regional-Centred Economic Choices to Shape this Decade' South-East Europe Review for Labour and Social Affairs 6(1/2): 7-16.

Sergi, Bruno S (2003b) Economic Dynamics in Transitional Economies: The Four-P Governments, EU Enlargement and the Bruxelles Consensus New York: International Business Press.

Sergi, Bruno S (2004) 'Understanding the EU-factor: The Balkan Regions as Recipients of FDI and Industries' South-East Europe Review for Labour and Social Affairs 7(4): 7-20.

Sergi, Bruno S (2005) ; The Balkans Jump on the Tax Rivalry Bandwagon' SouthEast Europe Review for Labour and Social Affairs 8(1): 7-18.

Sergi, Bruno S (2006) Central and Peripheral Regions in Europe: Can Tax Competition Attract Foreign Direct Investment Forever? Washington, DC: American Consortium on European Union Studies (ACES), ACES Cases No. 2006, 3.

Sergi, Bruno S. and Qerim R. Qerimi (2005) 'The European Union and its Prospective Enlargement to the South-East' South-East Europe Review for Labour and Social Affairs 8(4): 15-32.

Sergi, Bruno S. and Qerim R. Qerimi (2006a) 'Business Perspectives in Southeast Europe’ Transition Studies Review 13(3): 541-555.

Sergi, Bruno S. and Qerim R. Qerimi (2006b) 'Upgrading the Balkans Regional Infrastructure' South-East Europe Review for Labour and Social Affairs 9(1): 89-96.

Shleifer, Andrei and Robert Vishny (1993) 'Corruption' Quarterly Journal of Economics 108(3): 599-617.

Southeast European Times (2006) 'Rehn Urges Bulgaria to Show Results in Fight Against Organised Crime, Corruption'

http:/www.balkantimes.com/cocoon/setimes/xhtml/en_GB/features/setimes/features/ 2006/04/14/feature-01/ [accessed 14 April 2006].

Stiglitz, Joseph E (1998) Towards a New Paradigm for Development: Strategies, Policies and Processes Prebisch Lecture at UNCTAD, Geneva.

Svensson, Jakob (2005) 'Eight questions about corruption' Journal of Economic Perspectives 19(3): 19-42.

Treisman, Daniel (2000) 'The Causes of Corruption: A Cross National Study' Journal of Public Economics 76(3): 399-457.

United States Institute for Peace (2002) Lawless Rule versus Rule of Law in the Balkans Washington, DC: Special Report No. 97.

Wallis, John Joseph, Price Fishback and Shawn Kantor (2005) Politics, Relief and Reform: The Transformation of America's Social Welfare System during the New Deal NBER Working Papers 11080, National Bureau of Economic Research.

You, Jong-Sung and Sanjeev Khagram (2005) A Comparative Study of Inequality and Corruption John F. Kennedy School of Government Faculty Research Working Papers Series http://ksgnotes1.harvard.edu/Rsearch/wpaper.nsf/rwp/RWP04-001 [accessed 13 March 2005]. 